\title{
TOTAL UNCONJUGATED OESTROGEN AND PROGESTERONE CONCENTRATIONS IN PERIPHERAL BLOOD DURING THE OESTROUS CYCLE OF THE DOG
}

\author{
J. G. HADLEY \\ Department of Surgery and Obstetrics, Royal Veterinary College Field Station, \\ Hawkshead Lane, North Mimms, $\mathrm{Nr}$ Hatfeld, Herts
}

(Received 9th November 1974)

\begin{abstract}
Summary. From the beginning of pro-oestrus to the end of metoestrus, daily peripheral blood samples were withdrawn from six bitches. Further samples were obtained during anoestrus. Oestrogen values rose from the onset of pro-oestrus to attain a peak value of $25 \cdot 3 \pm 4.8 \mathrm{pg} / \mathrm{ml}$ on Day 1 of oestrus. Progesterone concentrations began to rise 2 days before the oestrogen peak, and reached their highest levels of $18.9 \pm 1.0 \mathrm{ng} / \mathrm{ml} 16$ days after the end of oestrus. After oestrus, an oestrogen rise was detected which reached a peak at Day 18 of metoestrus. The duration of oestrus was unrelated to the length of time that oestrogen levels were raised, or the maximum values were attained. No significant oestrogen levels were detected during anoestrus.
\end{abstract}

\section{INTRODUGTION}

Several investigations have been conducted recently into the endocrine changes associated with the oestrous cycle of the bitch. Bell, Christie \& YoungLai (1971) and Phemister, Holst, Spano \& Hopwood (1973) have measured changes in oestrogen concentrations during pro-oestrus and oestrus. Progesterone concentrations during oestrus and at intervals during metoestrus have been determined by Christie, Bell, Horth \& Palmer (1971), Spano, Tietz, Masken \& Hopwood (1971), Smith \& McDonald (1972, 1974), Phemister et al. (1973) and Sokolowski (1973).

Jones \& co-authors (1973) measured oestradiol-17 $\beta$ and progesterone in the peripheral plasma of three beagle bitches from the onset of pro-oestrus until the first few days of metoestrus, and subsequently at various intervals in two of these animals until 50 days after the end of oestrus. In the present study, total unconjugated oestrogens and progesterone were simultaneously measured in the peripheral blood of six bitches at daily intervals from the commencement of pro-oestrous bleeding until the end of metoestrus.

\section{MATERIALS AND METHODS}

Five mongrel bitches and one beagle were used in this study. The bitches were 445 
examined daily for signs of vulval swelling or bleeding. The first day of prooestrus was recorded as the first day of vulval bleeding, and each bitch was 'tried' daily with a male dog from this time until the end of oestrus. Vaginal smears were prepared daily from the first day of pro-oestrus until 2 to 4 days after the end of acceptance of the male.

Blood samples $(5 \mathrm{ml})$ were collected from either the cephalic or the saphenous vein of each bitch. In five cycles, samples were obtained daily for 95 days from the onset of pro-oestrus and in one other cycle daily for 75 days, followed by sampling at 2- to 3-day intervals for the next 20 days. Three animals were bled frequently in the 3 weeks before the anticipated onset of pro-oestrous bleeding, and two more were sampled daily for 5 weeks from 131 and 135 days after oestrus, respectively. In all cases, the blood samples were drawn into a syringe containing $0.1 \mathrm{ml}$ heparin at a strength of $5000 \mathrm{i} . \mathrm{u} . / \mathrm{ml}$, and were then transferred immediately to bijou bottles or plastic centrifuge tubes in which the samples were frozen and stored at $-20^{\circ}$ until they were assayed.

Total unconjugated oestrogen and progesterone concentrations were determined by the method of Challis, Heap \& Illingworth (1971), as described by Hadley (1973). The antiserum used in the oestrogen assay was prepared against oestradiol- $17 \beta$ and showed cross-reactions of $92 \%$ with oestrone, $52 \%$ with oestriol and $36 \%$ with oestradiol- $17 \alpha$ (Challis et al., 1971). The results described as total unconjugated oestrogen represent the amount of unconjugated oestrogen extracted from blood as detected by this antiserum.

The coefficient of variance at three oestrogen concentrations was determined by obtaining blood from a castrated male dog, to which $10 \mathrm{pg}, 17.5 \mathrm{pg}$ and 35 pg oestradiol-17 $\beta$ were added to $1-\mathrm{ml}$ aliquots. Values of $16.7 \%$ (number of aliquots $(n)=19), 15 \cdot 7 \%(n=10)$ and $12 \cdot 1 \%(n=17)$ were obtained at these levels. The assay blank in this system was $9 \mathrm{pg} / \mathrm{ml}$ and the recovery value was $77.5 \%$. The coefficient of variance in the progesterone assay was determined by adding $0.5,3.0$ and $5.5 \mathrm{ng}$ progesterone to $1 \mathrm{ml}$ blood. The respective values obtained at each of these concentrations was $21.5 \%(n=15), 13.2 \%(n=20)$ and $10.9 \%(n=14)$. A blank value of $0.3 \mathrm{ng} / \mathrm{ml}$ and a recovery figure of $89 \%$ were obtained in this assay procedure. In all cases, the results were corrected for the blank values and recovery figures.

\section{RESULTS}

The changes in total unconjugated oestrogen concentrations during the oestrous cycle are shown in Text-fig. 1. The mean lengths of pro-oestrus and oestrus for the bitches were calculated, and the individual daily values for each of these phases were transformed to the appropriate day in the average period on a $\%$ basis, i.e. if the duration of pro-oestrus in one bitch was 5 days, then the value for Day 1 was recorded at a time corresponding to $20 \%$ of the mean duration of pro-oestrus for the group. The mean values for each day of the uniform prooestrous and oestrous phases were then calculated. The mean daily metoestrous levels were obtained by direct calculation from the individual values for each day after the end of heat.

At the onset of pro-oestrus, the mean total unconjugated oestrogen value \pm 


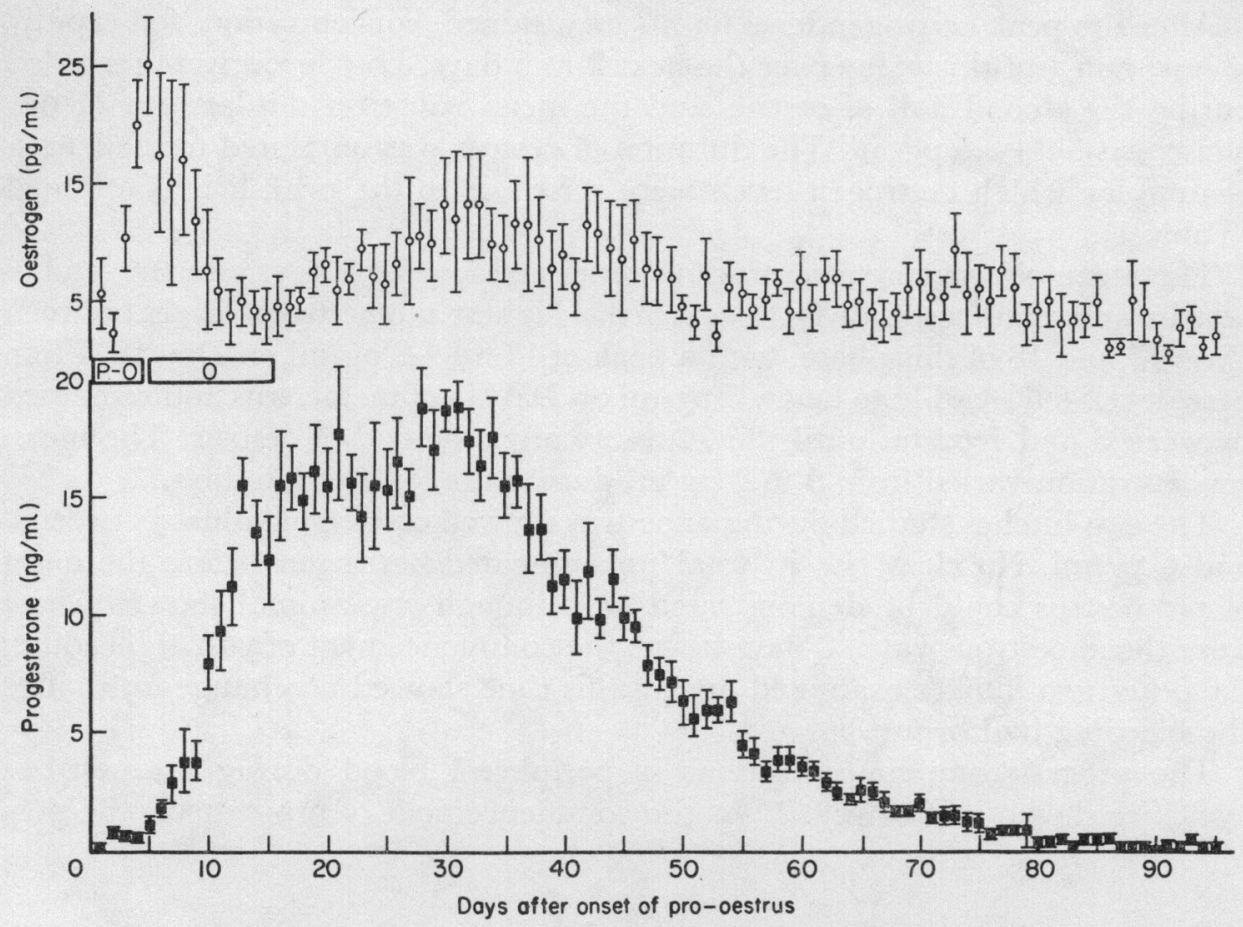

TExT-FIG. 1. Mean daily progesterone ( $⿴ 囗)$ and total unconjugated oestrogen $(0)$ concentrations during the oestrous cycles of six bitches. Vertical bars represent S.E.M. P-O, pro-oestrus; $\mathrm{O}$, oestrus.

S.E.M. for the six bitches was $5.9 \pm 3.0 \mathrm{pg} / \mathrm{ml}$ (range, 0 to $22.8 \mathrm{pg} / \mathrm{ml}$ ). The animals which showed the higher levels at this time also tended to have the higher peak values later during oestrus (Table 1). The oestrogen concentrations increased sharply during pro-oestrus to reach a peak on the last day of prooestrus or the first 2 days of oestrus in five of the six animals (see Text-fig. 2), although this was not achieved until the 4th day of oestrus in the remaining bitch. The highest mean daily value for the group was $25.3 \pm 4.8 \mathrm{pg} / \mathrm{ml}$ and was attained on the lst day of oestrus. The mean individual peak value for these cycles was $29 \cdot 5 \pm 7 \cdot 0 \mathrm{pg} / \mathrm{ml}$.

Table 1. Oestrogen values and the duration of pro-oestrus and oestrus in the bitch

\begin{tabular}{lcccc}
\hline Bitch & $\begin{array}{c}\text { Oestrogen conc. } \\
\text { at onset of } \\
\text { pro-oestrus }(\text { pg/ml) }\end{array}$ & $\begin{array}{c}\text { Peak oestrogen } \\
\text { value during } \\
\text { oestrus }(\text { pg/ml) }\end{array}$ & $\begin{array}{c}\text { Duration of } \\
\text { oestrus } \\
\text { (days) }\end{array}$ & $\begin{array}{c}\text { Combined duration } \\
\text { of pro-oestrus } \\
\text { and oestrus } \\
\text { (days) }\end{array}$ \\
\hline C & $22 \cdot 8$ & $57 \cdot 6$ & 15 & 18 \\
E & $6 \cdot 3$ & $36 \cdot 0$ & 11 & 14 \\
B & $6 \cdot 2$ & $36 \cdot 1$ & 10 & 14 \\
D & $3 \cdot 5$ & $18 \cdot 7$ & 10 & 17 \\
A & $2 \cdot 5$ & $18 \cdot 1$ & 8 & 11 \\
J & N.D. & $10 \cdot 7$ & 14 & 19 \\
\hline
\end{tabular}

N.D., not detectable. 
After the peak oestrogen level had been attained, concentrations fell rapidly to less than $\frac{1}{3}$ of this value over the next 2 to 5 days. Low levels were recorded during the second half of oestrus and the mean value on the last day of this phase was $3.8 \pm 2.5 \mathrm{pg} / \mathrm{ml}$. The duration of oestrus was unrelated to the length of time for which oestrogen levels were raised or to the peak height attained (Table 1).

The mean oestrogen concentrations remained low for 3 days after the end of oestrus and then rose slowly to reach the highest metoestrous levels between Days 15 and 18 of this phase, with a peak of $13.3 \pm 4.3 \mathrm{pg} / \mathrm{ml}$ on Day 18 . From here, levels fell steadily to below $7 \mathrm{pg} / \mathrm{ml}$ on Day 33 of metoestrus and remained between 3 and $7 \mathrm{pg} / \mathrm{ml}$ until the 74th day after the end of oestrus. The mean concentration varied from 0 to $2 \mathrm{pg} / \mathrm{ml}$ during the following 6 days.

The two bitches studied during anoestrus showed oestrogen values between 0 and $6 \mathrm{pg} / \mathrm{ml}$. No clear rise in total unconjugated oestrogen before the onset of pro-oestrus could be demonstrated as, although one animal showed a rise from the anoestrous value 8 days before the commencement of vulval bleeding, the other two bitches examined during this time showed no change until after the bleeding had begun.

The progesterone concentrations in peripheral blood during the oestrous cycle are shown in Text-fig. 1. At the commencement of pro-oestrus, the pro-

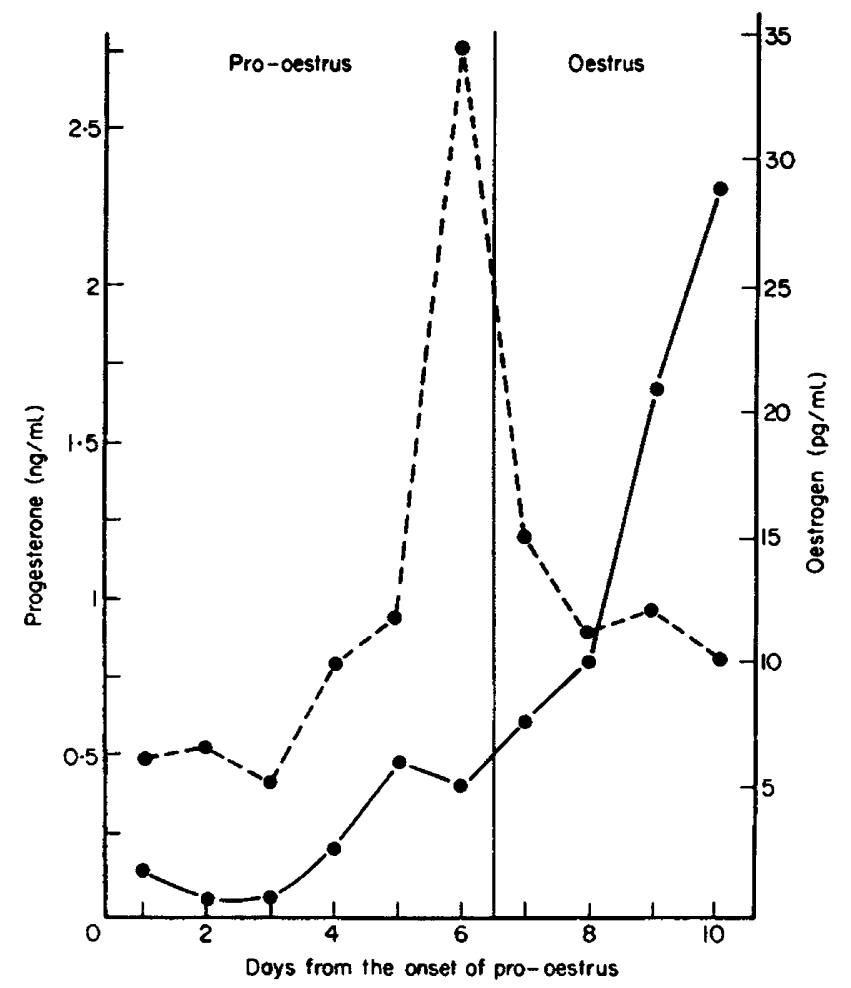

TExT-Fig. 2. Progesterone (-) and total unconjugated oestrogen (-- concentrations in one bitch during pro-oestrus and early oestrus. 
gesterone level was $0 \cdot 2 \pm 0 \cdot 1 \mathrm{ng} / \mathrm{ml}$ and remained low throughout this phase. The progesterone concentrations increased slightly in late pro-oestrus due to the small rise which occurred 1 to 2 days before the peak oestrogen level was attained (Text-fig. 2), and the value on Day l of oestrus was $1.2 \pm 0.5 \mathrm{ng} / \mathrm{ml}$. The mean daily concentrations rose steadily during the first 5 days of oestrus and then very rapidly over the following 4 days. The rate of increase became more gradual during the last 2 days of oestrus and at the end of this phase the mean progesterone level was $12 \cdot 3 \pm 2 \cdot 0 \mathrm{ng} / \mathrm{ml}$.

The slower rate of increase was continued until the daily mean peak value of $18.9 \pm 1.0 \mathrm{ng} / \mathrm{ml}$ was reached 16 days after the end of heat. The mean individual peak value was $23.2 \pm 1.2 \mathrm{ng} / \mathrm{ml}$ and occurred on the $13.3 \pm 1.6$ day of metoestrus. The time of the progesterone peak varied from 13 to 17 days after oestrus in five bitches, but in the sixth bitch the peak level was reached only 6 days after the end of oestrus. Mean daily progesterone concentrations fell steadily between the 16th and 24th day of metoestrus before remaining fairly constant at between 10 and $12 \mathrm{ng} / \mathrm{ml}$ for 6 days. Levels subsequently fell at a progressively slower rate to become less than $0.2 \mathrm{ng} / \mathrm{ml}$ on the $72 \mathrm{nd}$ day after the end of heat. The temporary break in the progressive decline in progesterone concentrations from their peak value was a feature of each of the cycles studied.

\section{DISCUSSION}

The highest oestrogen values recorded in this study on the bitch were comparable to those reported by Bell et al. (1971). They ranged, however, from the highest values reported by Jones et al. (1973) to twice the peak levels recorded by these authors. This may reflect the fact that Jones et al. (1973) used an assay procedure which was specific for oestradiol-17 $\beta$, whereas total unconjugated oestrogens were detected in the present study and that of Bell et al. (1971).

In the present work, the rise in oestrogen concentrations to their highest values and their subsequent decline during oestrus were similar to those reported by Jones $e t$ al. (1973), but much more rapid than those recorded by previous authors. The over-all spread of individual peak oestrogen values was 5 days, with five of the six cycles giving a variation of 3 days. This was in agreement with the results of Jones et al. (1973), although Bell et al. (1971) reported a variation of 10 days, using Day 1 of oestrus as the reference point, in the three bitches which they studied. No relationship could be established between the length of oestrus and the magnitude of the associated oestrogen peak. A similar observation was made by Bell et al. (1971). The oestrogen values were seen to fall during oestrus, and the decrease was marked after the peak concentration had been attained. Consistently high oestrogen levels were determined throughout pro-oestrus by Phemister et al. (1973) and no clear peak was demonstrable although concentrations fell gradually after Day 2 of oestrus. Metzler, Eleftheriou \& Fox (1966) also recorded a fall in oestrogen values as oestrus progressed. The latter two groups recorded peak values 200 and 10,000 times higher than those found in the present work. This difference may be related to the different assay techniques employed. The changes in urinary oestrogen concentrations reported by Batchelor, Bell \& Christie (1971) during pro-oestrus and oestrus 
were much more gradual than those seen here in peripheral blood, and the levels did not decline from their highest values until late oestrus.

In all bitches except one, the peak oestrogen concentrations were attained within 2 days of first acceptance of the male. The low levels of this hormone observed in mid- and late oestrus were below those of the non-receptive stages of late pro-oestrus and early metoestrus.

Oestrogen concentrations were elevated between Days 10 and 22 of metoestrus and the highest values during this period coincided with the highest progesterone levels. After this period, the oestrogen values fell to below $7 \mathrm{pg} / \mathrm{ml}$ and did not exceed this amount for the remainder of metoestrus. Bell et al. (1971) examined peripheral plasma samples from one bitch during the first 42 days of metoestrus and found that oestrogen levels fluctuated between 18 and $45 \mathrm{pg} / \mathrm{ml}$, although no pattern could be established. It is probable that the corpus luteum is the source of the oestrogen produced during the luteal phase and canine luteal cells have been shown to increase their capacity to produce this steroid as they age and begin to regress (Fowler \& Feldman, 1970).

Only one out of three bitches showed a demonstrable rise in oestrogen before the onset of pro-oestrus, although early changes in the histological appearance of the uterus can be clearly seen at the onset of pro-oestrus (Arenas \& Sammartino, 1939; Hadley, 1973). This could be an indication of the sensitivity of the canine uterus to low levels of oestrogen which may have been below the sensitivity of the assay technique used here.

Progesterone levels were raised up to 2 days before the oestrogen peak in agreement with Vogel \& Van der Horst (1971) who described a rapid increase in the progesterone content of the canine ovary 1 to 2 days before ovulation. Christie et al. (1971) found no clear preovulatory progesterone rise in peripheral plasma. Phemister et al. (1973) demonstrated rising progesterone levels up to 4 days before ovulation was thought to occur. The fact that earlier workers did not detect any progesterone in ovarian venous blood at this time could be due to lack of sensitivity of the assays available to them. Leavitt, Bosley \& Blaha (1971) concluded that the preovulatory progesterone rise came from the preovulatory follicles and the interstitium of the ovary.

The highest mean progesterone concentration was recorded on Day 16 of metoestrus, with individual peak levels in the six cycles ranging from the 6th to the 17th day of metoestrus. The variations which exist between individuals are noteworthy. The time of highest progesterone concentrations in non-pregnant bitches has been reported as the last day of oestrus (Smith \& McDonald, 1972), Days 4 to 8 of metoestrus, (Christie et al., 1971), approximately Day 10 of metoestrus (Jones et al., 1973) and Days 16 to 21 of metoestrus (Spano et al., 1971).

The decline in the mean daily progesterone concentrations to $<0.2 \mathrm{ng} / \mathrm{ml}$. 72 days after the end of oestrus was temporarily interrupted by a period of relative stability between Days 24 and 30 of metoestrus which has not previously been reported. Christie et al. (1971) recorded concentrations in peripheral plasma of below $0.5 \mathrm{ng} / \mathrm{ml} 60$ days after oestrus whilst Spano et al. (1971) found progesterone to decline to a low level by Days 54 to 58 of metoestrus. Smith \& McDonald (1972) failed to detect progesterone in peripheral plasma 70 days 
after oestrus. The duration of metoestrus according to the present results, is approximately 78 days and is slightly less than the estimate (between 80 and 90 days) made by Evans \& Cole (1931), based on their histological studies of the genital tract.

\section{AGKNOWLEDGMENTS}

The author would like to extend thanks to Professor G. H. Arthur for his encouragement and for providing research facilities, and to Dr D. E. Noakes for his criticism of the text. Technical assistance was given by Miss M. A. Lemon, Mrs J. D. Sutton and Mrs G. E. Clarke. Financial support was kindly provided by Glaxo Laboratories Ltd, and Mrs M. Hughes typed the manuscript.

\section{REFERENCES}

Arenas, N. \& Sammartino, R. (1939) Le cycle sexuel de la chienne étude histologique. Bull. Histol. appl. Physiol. Path. 16, 229-259.

Batchelor, A., Belx, E. T. \& Christie, D. W. (1971) Urinary oestrogen levels in the beagle bitch. $\mathcal{F}$. Endocr. 51, xxvi-xxvii.

Bell, E. T., Christie, D. W. \& YoungLar, E. V. (1971) Plasma oestrogen levels during the canine oestrous cycle. J. Endocr. 51, 225-226.

Ghallis, J. R. G., Heap, R. B. \& Illingworth, D. V. (1971) The plasma concentrations of oestrogen and progesterone in non-pregnant, pregnant and lactating guinea pigs. F. Endocr. 51, 333-345.

Christie, D. W., Bell, E. T., Horth, C. E. \& Palmer, R. F. (1971) Peripheral plasma progesterone levels during the canine oestrous cycle. Acta endocr., Copenh. 68, 543-550.

Evans, H. M. \& Cole, H. H. (1931) An introduction to the study of the oestrous cycle in the dog. Mem. Univ. Calif. 9, 65-118.

Fowler, E. H. \& FeLdman, M. K. (1970) Histochemical demonstration of hydroxysteroid dehydrogenase activity in the mature canine ovary. Gen. $E^{\circ}$ compar. Endocr. 14, 484-496.

HADLEY, J. C. (1973) A study of ovarian and uterine histology and of reproductive endocrinology in normal and in some genitally abnormal bitches. Ph.D. thesis, University of London.

Jones, G. E., Boyns, A. R., Cameron, E. H. D., Bell, E. T., Christie, D. W. \& Parkes, M. F. (1973) Plasma oestradiol, luteinizing hormone and progesterone during the oestrous cycle in the beagle bitch. F. Endocr. 57, 331-332.

Leavitr, W. W., Bosley, C. G. \& Blaha, G. C. (1971) Source of ovarian preovulatory progesterone. Nature, New Biology, 234, 283-284.

Metzler, F., Eleftheriou, B. E. \& Fox, M. (1966) Free estrogens in dog plasma during the estrous cycle and pregnancy. Proc. Soc. exp. Biol. Med. 121, 374-377.

Phemister, R. D., Holst, P. A., Spano, J. S. \& Hopwood, M. L. (1973) Time of ovulation in the beagle bitch. Biol. Reprod. 8, 74-82.

Smrth, M. S. \& MaDonald, L. E. (1972) Serum levels of luteinizing hormone and progesterone during the estrous cycle, pseudopregnancy and pregnancy in the dog. Fedn Proc. Fedn Am. Socs exp. Biol. $31,257$.

SMITH, M. S. \& MaDonald, L. E. (1974) Serum levels of luteinizing hormone and progesterone during the estrous cycle, pseudopregnancy and pregnancy in the dog. Endocrinology, 94, 404-412.

Sokolowski, J. H. (1973) Reproductive features and patterns in the bitch. F. Am. Anim. Hosp. Ass. 9, $71-81$.

Spano, J. S., Tietz, W. J., Masken, J. F. \& Hopwood, M. L. (1971) Progestin and luteinizing hormone levels in plasma of female dogs. Physiologist, Wash. 14, 234.

Vogel, F. \& VAN DER Horst, G. J. G. (1971) Een onderzoek naar de hormonale samenstelling van de ovaria bij de hord tijdens de cyclus. Tijdschr. Diergeneesk, 96, 1637-1648. 